Лесь Белей

Інститут мовознавства ім. О. Потебні НАН України відділ мов України

\section{ЕВОЛЮЦІЯ МОВ: МОДЕЛЬ СИНГУЛЯРНОСТЕЙ}

Стаття описує модель мовних сингулярностей як інструмент багаторівневого зображення мовної еволюції з урахуванням внутрішньомовних процесів та впливів сусідніх мов. Автор пропонує синтетичну модель, за допомогою якої можна зображати мовні зміни на різних рівнях, беручи до уваги регіональні різновиди, кодифіковані стандарти, швидкість та інтенсивніст -

Ключові слова: мовна сингулярність, діахронія, синхронія, мова, діалект, мовна політика

The article describes the model of linguistic singularities. This is a concept which enables us to map the evolution of languages on various levels, taking into account intralinguistic processes and the influences of neighboring languages. The author proposes a synthetic model which makes it he influences of neighboring languages. The author proposes a synthetic model which makes possible to demonstrate language changes on various levels, taking into account regional variation, the history of the Ukrainian language.

Key words: linguistic singularity, diachrony, synchrony, language, dialect, language policy.

У другій половині XIX ст. А. Шлейхер та Й. Шмідт запропонували дві концепції еволюції мов: теорію родовідного дерева (дивергенція), і теорію хвиль (конвергенція). Шлейхер переконував, що мови походять з однієї спільної прамови і з плином часу відбувся поділ на різні мовні сім'ї, які поділилися на окремі групи, а ті - на окремі мови. За структурою ця схема нагадує дерево, де одного стовбура виростають товсті гілки, які потім переходять у численні тонші відгалуження див. (Schleicher 1861).

Учень А. Шлейхера, Й. Шмідт розробив теорію хвиль, згідно з якою мовні явища мають свої вілдалені центри, що поширюють відщентрові хвилі, як кола на воді, які можуть накладатися одні на одних див. (Schmidt 1872).

Насправді ці теорії доповнюють одна одну, просто Шлейхерівська модель показує глибокий вертикальний історичний зріз, а модель Шмідта ілюструє внутрішньомовні зміни, мовні контакти і впливи у меншій часовій перспективі. Процес дивергенції не виключає конвергенції і навпаки.

Поєднання цих двох теорій ілюструє мовну спорідненість, механіку мовних впливів, однак усе ще залишається кілька питань.

1. Як саме відбувається дивергенція? Коли з одної мови утворюються дві/три чи більше інших?

2. Як саме дивергенція поєднується 3 конвергенцією. Чи відбувається взаємовплив?
Еволюиія мов: иодель синаулярностей

3. Чи дивергенція і конвергенція - це єдині механізми творення нових мов?

4. Чи впливає на мовну еволюцію кодифікація та літературна традиція?

5. Який вплив позамовних факторів на ці процеси?

У цьому дослідженні ми запропонуємо модель, що дає відповіді на ці питання.

Основна одиниця родовідного дерева Шлейхера - це мова. Термін мова позначає доволі комплексне явище, iї формують різні територіальні та соціальні діалекти. Варіація також відбувається на кодифікаційному рівні, оскільки паралельно можуть існувати літературні стандарти та розмовні різновиди. На територіальному, соціальному та кодифікаційному рівні відбувається суттєва варіація в рамках однієї мови.

Поняття «мова» і «діалект» вживаються не тільки у лінгвістиці, нерідко до цих термінів звертається політика, оскільки довкола окремішності мов часто вибудовуються національні політичні проекти. Через це межі між поняттями «мова» і «діалект» сильно розмиті.

Політична заангажованість часто стає причиною того, що діалект називають окремою мовою і навпаки, окрему мову дефініюють як діалект. Дослідники використовують різну доказову базу, тому важко виділити універсальні загальновизнані параметри, які би чітко розмежовували ці поняття.

Щоб побудувати повнішу і універсальнішу модель мовної еволюції доречно ввести нейтральний термін для позначення окремого мовного коду (щоб не використовувати заполітизовані терміни «мова» $\mathrm{i}$ «діалект»).

3 цієї метою можна використати поняття сингулярності, розроблене фізиком Джеймсом Максвеллом у 1873 році. Він вжив цей термін для окреслення нестабільності системи, коли невелика зміна може дати великий ефект (Maxwell 1882: 440).

В математиці англійським терміном singularity позначається особлива точка голоморфічної функції, в якій функція не визначена, ії границя нескінченна або границі не існує див. (Сжов 2012).

Англійським терміном singularity point of curve позначається особлива точка кривої: будь-яка точка кривої, яка не $є$ регулярною (вузлові точки, у яких крива сама себе перетинає, ізольовані точки, розташовані окремо від кривої, точки повернення і загострення, точки самодотику, точки зламу, точки закінчення, асимпотичні точки, у яких крива наближається на нескінченно малу відстань, точки перегину) див. (Борисенко 1995).

Поняття технологічної сингулярності в теорії інформаційних технологій позначає момент, коли штучний інтелект стане потужнішим за людський (Shanahan 2015: 233].

Також поняття сингулярності використовують у астро-фізиці (Hawking 2018), механіці (Gosselin 1990) та дослідженнях клімату (Lamb 1950).

Термін «мовна сингулярність» застосовувався рідко. Ми зафіксували два використання. У статті Towards a linguistic singularity Ш. Хан вжив цей термін на позначення стану, коли на світі запанує одна мова (від singularity - однина) (Khan 2018).

Славистика XXIII/1 (2019) 
Р. Кащула та А. Мостерт вживають поняття «мовна сингулярність» на позначення нової форми комп'ютерно-людської комунікації у рамках технологічного детермінізму (Kaschula, Mostert 2018).

Перше вживання цього терміну цілком метафоричне і не має нічого спільного з визначенням Максвелла, а друге стосується саме сингулярності в інформаційних технологіях.

У нашому трактуванні цей термін має інше значення, наближене до максвеллівського.

Г. Гольцкампер відзначає такі властивості максвеллівської сингулярності, які можна застосувати до мовної еволюції:

1. Нестабільність: сингулярності залежать від наслідків (малі зміни дають великі наслідки).

2. Системна пов'язаність: сингулярності репрезентують особливості системи і вражають їі ідентичність.

3. Унікальність: сингулярності відзначаються не квантитативними показниками, але якісною унікальністю.

4. Незворотність: спричинені зміни систем великою мірою незворотні.

5. Суб'єктивність: усвідомлення залежить від людського сприйняття та досвіду.

6. Випадковість: сингулярності часто сприймають за випадковість бо їхні причини і наслідки погано вивчені.

7. Складність: поява сингулярностей часто пов'язана зі складністю системи та іiї оточення.

8. Взаємодія: сингулярності часто з'являються внаслідок взаємодії двох систем (Holzkämpfer 1996: 91).

Отже, мовна сингулярність - це точка, в якій мовний різновид акумулює достатню кількість відмінностей від першоджерела, щоб утворити новий окремий мовний код. Залежно від політичної інтерпретації мовну сингулярність можна визначити як новоутворену мову або діалект (детальніше про це нижче).

Для побудови теорії мовних сингуляростей потрібно прийняти такі гіпотези:

1. Мова весь час розвивається. Вона не стоїть на місці.

2. Мовні зміни відбуваються одночасно на різних іiі рівнях: лексика, фразеологія, синтаксис, морфологія та фонетика.

3. Зміни відбуваються з різною інтенсивністю, залежно від внутрішньомовних та зовнішніх обставин.

4. Причинами змін $€$ як внутрішньомовна еволюція, так і впливи сусідніх мов.

5. Мовні зміни відбуваються по-різному в різних частинах та сферах ареалу однієї мови.

6. На мовні зміни впливає мовне планування та мовна політика.

7. Інтерпретація мовних змін не завжди відображає реальний стан мовних змін.

Ідеальний розвиток ізольованої мови можна зобразити на графіку див. Схему 1.
Еволючія иов: иодель сингулярностей

Схема 1

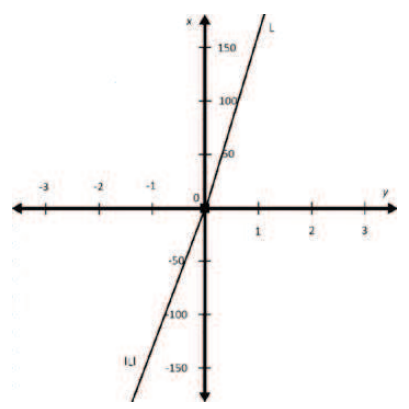

Bicь $x$ позначає час $(50,100,150$ років). Точка 0 - час утворення окремої мовної сингулярності.

Прикладова мова на графіку є частиною мовної еволюції, вона не 3'явилася на пустому місці. Половина осі $x$ з від'ємним значенням показує походження i icторію цієї мови, коли вона була чистиною іншої мови (діалектом $|\mathrm{L}|$ ). На цьому графіку вона з'являється на позначці -200 років. За цей період вона віддалилася від мови свого походження настільки, що стала самостійною мовною сингулярністю, дійшла до точки нуль (від якої утворюються осі координат нової сингулярності) $\mathrm{i}$ далі уже розвивається як окрема мова L (додатні значення на осі $x$ ).

На осі $y$ показано три ступені віддаленості від точки утворення мовної сингулярності під час еволюції мови: 1 - мінімальні відмінності; 2 - середня віддаленість; 3 - віддаленість, достатня для творення нової мовної сингулярності.

При мінімальній відмінності мова за певний період часу еволюціонує і уже відрізняється від тої, якою була в момент творення мовної сингулярності. При середній віддаленості відмінностей назбирується більше, проте мова все ще $\epsilon$ різновидом тієї самої мовної сингулярності. Відмінності не перевищують $30 \%$. Третя поділка показує суттєву кількість мовних змін, достатніх для творення нової сингулярності $(40-60 \%)$.

Під час розвитку ця ідеальна прикладова мова змінилася мінімально, а отже віддалилася від точки нуль на осі $y$ поступово. Протягом ста п'ятдесяти років вона дійшла до першої поділки віддалення від точки сингулярності.

Тут і далі прикладовий розиток мов та різних іï рівнів показано схематичними прямими або кривими, хоча насправді мовна еволюція рідко буває такою симетричною. Схематичні лінії використано для зручнішої ілюстрації запропонованої концепції, яка також дозволяє застосовувати високу деталізацію.

Лінія L, що позначає еволюцію прикладової мови - це середній показник за трьома різними параметрами:

Славистика XXIII/1 (2019) 
1) Лексико-фразеологічні зміни (La)

2) Морфологічно-синтаксичні зміни (Lb)

3) Фонетико-просодичні зміни (Lc)

Деталізований розвиток див. Схему 2.

Схема 2

На схемі видно, що найбільше змін відбулося на рівні La (лексика i фразе-

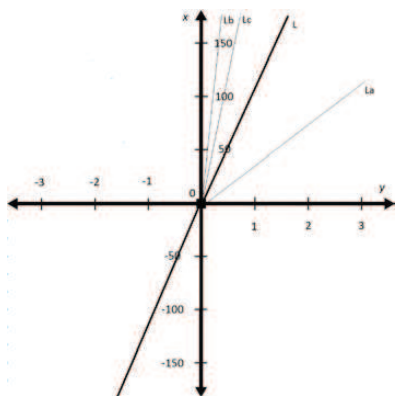

ологія), на рівні морфології та синтаксису (Lb), а також фонетики та просодії $(\mathrm{Lc})$ зміни менш інтенсивні. Таким чином лінія L - це середнє арифметичне ліній $\mathrm{La}, \mathrm{Lb}$ та Lc.

Компоненти La, Lb та Lc однаковою мірою важливі. Саме на їх основі будується середній показник загальної мовної зміни, який можна вирахувати у відсотках. Суттєва зміна будь-якого з цих трьох компонентів призведе до суттєвої трансформації мови загалом. Наприклад, якщо не зміниться морфологія, синтаксис, фонетика і просодія, але повністю поміняється лексика і фразеологія, то це призведе до утворення нової мовної сингуляності. I так 3 кожним компонентом.

Трьом компонентам також характерна географічна та соціальна варіація, тобто в різних частинах мовного ареалу зміни на всіх трьох рівнях можуть відбуватися по-різному. Таким чином вони також $€$ усередненими показниками.

Наприклад, лексико-фразеологічна варіація може мати чотири регіональні різновиди (La1, La2, La3, La4) з різною інтенсивністю віддалення від точки утворення мовної сингулярності див. Схему 3.
Схема 3

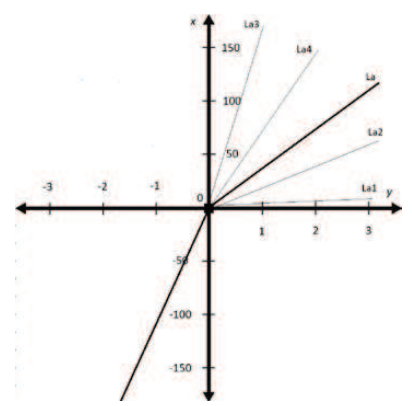

Кожен 3 різновидів, можна так само поділити на ще менші різновиди, а ті на ще менші аж до рівня індивідуальних користувачів мови.

На цій схемі показано чотири рівномірні і рівносильні групи La. Однак часто буває так, що одні групи чисельніші і впливовіші за інші. Це слід враховувати (лінії можна зображати різною товщиною). Так само з часом деякі групи стають чисельніші, а деякі навпаки зменшуються. Це так само можна зобразити на графіку (Схема 4).

Схема 4

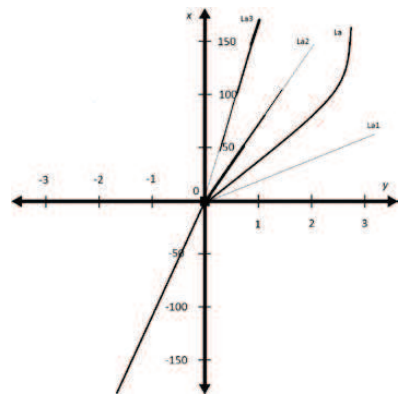

У цьому прикладі різновид La1 найменш численний регіональний різновид лексико-фразеологічних змін. Він зазнав найбільшого віддалення від точки творення сингулярності. Різновид La2 перші 50 років був найчисельнішим, але, дійшовши до позначки 150 років за своєю чисельністю наблизився до La1.

Славистика XXIII/1 (2019) 
Різновид La3 навпаки починав зі слабких позицій, але за 150 років став найчисельнішим. Зміна в чисельності призвела до того, що загальна пряма La не piвна, а крива, бо відображає інтенсивніші та популярніші явища.

Поки ми розглядали розвиток мови без урахування впливу інших мов. На графіку рівень впливу іншої мовної сингулярності позначається на шкалі $y$ від'ємними значеннями: -1 - незначний вплив, - 2 - середній вплив, -3 - поглинання іншою сингулярністю.

Вплив може бути суперстратно-субстратним, адстратним. Також це може бути результат креолізації тощо.

Вплив сусідньої мовної сингулярності може відбуватися не на усіх рівнях, а тільки на деяких. На Схемі 5 показано прикладовий вплив на мову L.

Схема 5

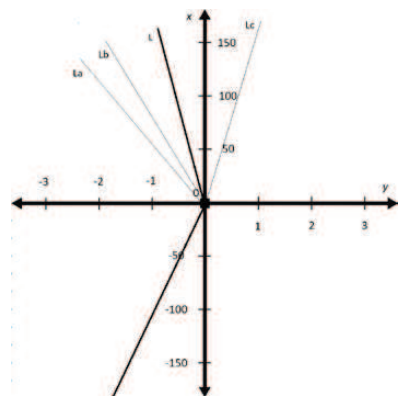

На лексико-фразеологічному рівні мова L зазнала суттєвого впливу сусідньої мовної сингулярності, трохи менший вплив на морфологічно-синтаксичному рівні, натомість фонетико-просодочний рівень залишився без впливу, але віддалився від сингулярності так само (внутрішньомовна еволюція). Таким чином загальна лінія еволюції мови L майже дійшла до рівня -1 за 150 років.

Далі ми розглянемо три сценарії утворення нових мовних сингулярностей:

1) переродження;

2) дивергенція;

3) синтез.

Переродження - це еволюція мови через внутрішні мутації: стара мовна сингулярність накопичує достатню кількість змін для переродження в нову (доходить до поділки 3 на шкалі у) див. Схему 6.

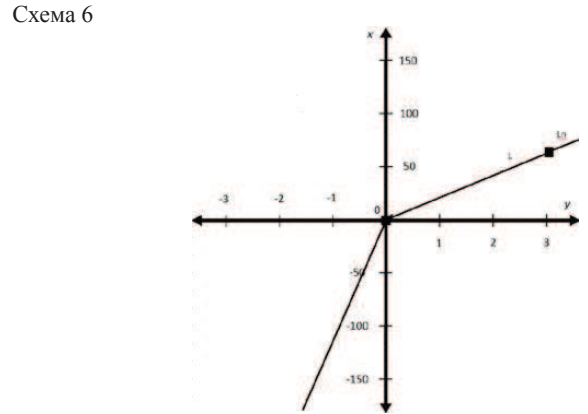

Причиною для переродження може бути природня лінгвальна еволюція мови на трьох рівнях або екстралінгвальні впливи (вимирання, інтенсивний зріст популяції, переселення чи будь-які інші зміни в кількісному балансі регіональних різновидів мови).

У дивергентному сценарії зміни концентруються в кількох різновидах, і коли розвиток мови доходить до третьої поділки на шкалі $y$, відбувається дивергенція на дві (або більше) нові сингулярності див. Схему 7.

Схема 7

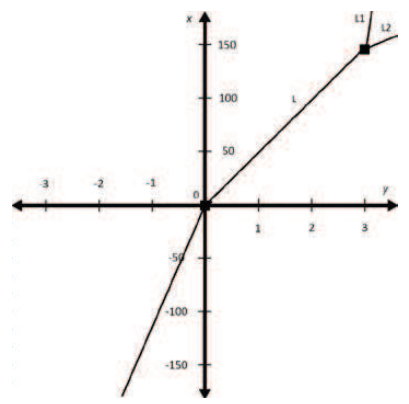

Ці два сценарії можуть відбуватися як під впливом внутрішньомовної еволюції $(\mathrm{y}=1,2,3$.$) , так і під впливом чужих мов (y=-1,-2,-3)$. На наступній схемі показано ці два механізми на трьох рівнях мови - лексико-фразеологічного $(\mathrm{La})$, морфологічно-синтаксичного (Lb) та фонетико-просодичного (Lc).

Внутрішнє переродження показано на прикладі внутрішньомовної еволюції, а дивергенцію на прикладі зовнішніх впливів, хоча ці сценарії творення нових сингулярностей можуть відбуватися в обох контекстах див. Схему 8. 
150 Лесь Белей

Схема 8

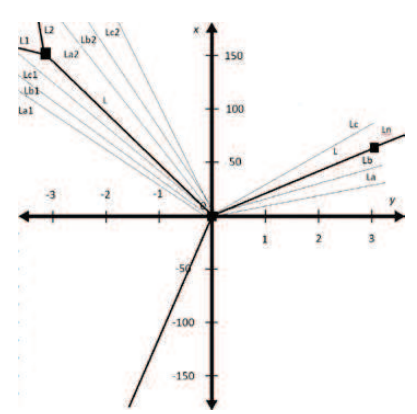

На прикладі внутрішнього переродження видно, що на всіх трьох рівнях мови не сформувалися окремі різновиди, тому мова просто переродилася у нову мовну сингулярність. Натомість на прикладі дивергентної моделі виділилися два регіональні різновиди з різним ступенем наближення до іншої мови. La1, Lb1, Lc1 зазнали інтенсивнішого впливу сусідньої мови і сформували мовну сингулярність L1, а в іншому різновиді на рівнях лексика-фразеологія, морфологія-синтаксис, фонетика-просодія (La2, Lb2. Lc2) вплив менший і повільніший, тому утворилася окрема мовна сингулярність L2.

Синтетичний сценарій утворення нової мовної сингулярності - це поєднання двох сингулярностей, що творять нову третю мовну сингулярність (або кілька нових мовних сингулярностей). Найчастіше цей сценарій відбувається під час креолізації див. Схему 9.

Схема 9

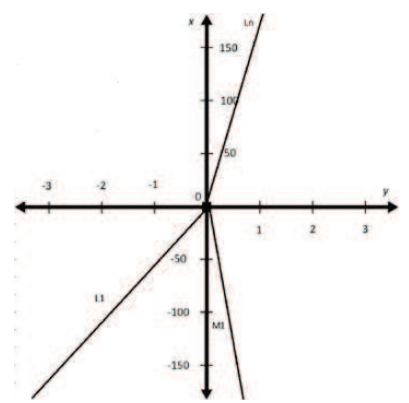

На цьому прикладі показано, що мова L1 більше наблизилася до M1, ніж M1 до L1. Таким чином в новій мовній сингулярності Ln більше елементів M1,
Еволючиія мов: модель сингулярностей

ніж L1. Синтез може відбуватися шляхом різних комбінацій мовних рівнів обох мов La1, Lb1, Lc1 та Ma1, Mb1, Mc1. Також у синтезі можуть взаємодіяти різні регіональні рівні обох мов. Усі ці параметри слід враховувати.

Мовне планування та мовна політика можуть мати суттєвий вплив на еволюцію мовної сингулярності.

Літературний стандарт - це штучний конструкт, створений на основі реальної мовної сингулярності (одного або кількох діалектів). Розвиток літературного стандарту може збігатися 3 лінією розвитку мовної сингулярності, але частіше літературна норма відстає від змін сингулярності. На Схемі 10 показано приклад еволюції мовної сингулярності та літературного стандарту.

Схема 10

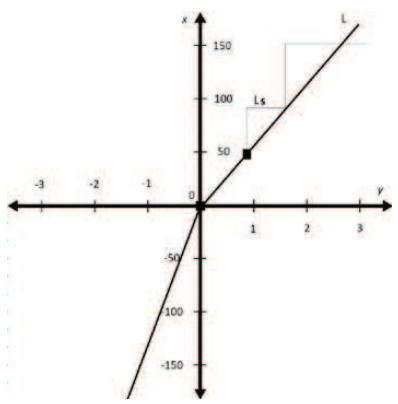

У точці 0 утворилася мовна сингулярність (L). Через 50 років її стандартизовано в літературну мову (Ls). За основу стандарту взято реальний стан мовної практики на той час. Отже точка утворення стандарту лежить на прямій сингулярності.

Сингулярність продовжила свою внутрішньомовну еволюцію, але стандарт зафіксував норму станом на 50 років, тому відділився від лінії сингулярності і не відхилився на осі $y$ аж до 90-го року. Тоді стандарт переглянули і знову наблизили до актуального стану мовної сингулярності. Він знову не змінювався до 150 років. Тут його переглянули радикально і кодифікували певні норми 3 випередженням. Стандартизований варіант теоретично може передбачити еволюцію мови, але тільки у близькій часовій перспективі.

На Схемі 11 показано два регіональні відгалуження однієї мовної сингулярності: одне $|\mathrm{L} 1|$ за 50 років зазнало сильного суперстратного впливу, інше $|\mathrm{L} 2|$ показало внутрішньомовне віддалення від точки утворення мовної сингулярності. Після ефективного застосування мовної політики та мовного планування, їх вдалося наблизити до початкового стану і відновити спільну мовну сингулярність L за сто років.

Славистика XXIII/1 (2019) 
Схема 11

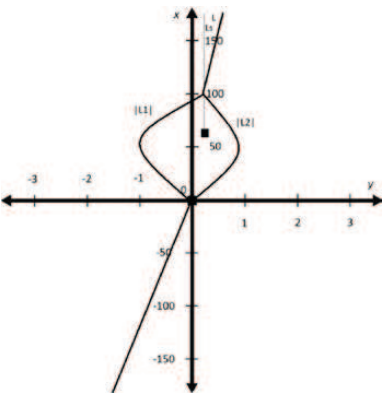

Реалізувати об'єднання двох регіональних різновидів допоміг літературний стандарт Ls кодифікований на 60 році існування мовної сингулярності. В його основу ліг компромісний варіант між $|\mathrm{L} 1|$ та $|\mathrm{L} 2|$ (ближчий до |L2|). На 100 році два різновиди наблизилися до літературного стандарту і продовжили свою мовну еволюцію, а стандарт не переглядали.

Регіональні різновиди можуть еволюціонувати цілком по різному. Ось кілька гіпотетичних варіантів на Схемі 12.

Схема 12

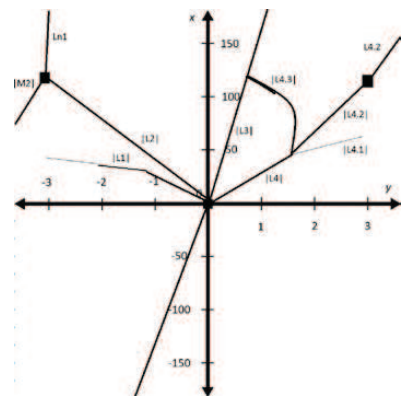

Регіональний різновид $|\mathrm{L} 1|$ зазнав впливу сусідньої сингулярності і за 50 років ставав дедалі менш численним, поки його не поглинула сусідня сингулярність. Різновид $|\mathrm{L} 2|$ об'єднався з різновидом сусідньої мови |M2| і утворив нову синтетичну мовну сингулярність Ln1. Різновид $|\mathrm{L} 3|$ проходив поступову повільну внутрішньомовну еволюцію. Різновид $|\mathrm{L} 4|$ за 50 років поділився на малочисельний підрізновид |L4.1|, що поступово зник, підрізновид |L4.2.| (що утворив
Еволючія мов: модель сингулярностей

нову мовну сингулярність L4.2.) і підрізновид |L4.3| що після ста років став чисельніший і влився у різновид $|\mathrm{L} 3|$.

Творення нової мови може не завжди збігатися 3 утворенням мовної сингулярності, оскільки це радше залежить від політичної інтерпретації. Приклад на Схемі 13

Схема 13

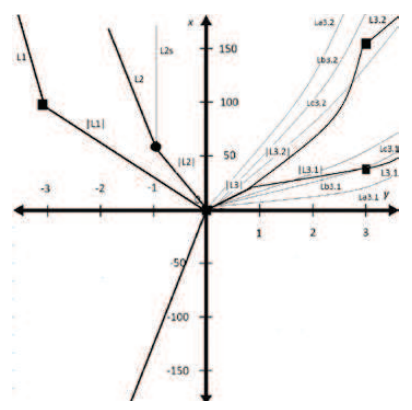

Мова L1 утворилася з природно утвореної мовної сингулярності (діалект $|\mathrm{L} 1|$ дійшов до поділки -3 (максимальний вплив сусідньої мовної сингулярності), що стало причиною для утворення нової мовної сингулярності. Регіональний різновид |L2| також зазнав впливу сусідньої мови. Вплив був меншим, за 50 років діалект |L2| віддалився до позначки -1 від точки утворення мовної сингулярності (наприклад, з'явилося багато лексико-фразеологічних запозичень). Використовуючи цю незначну відмінність, через політичні обставини різновид $|\mathrm{L} 2|$ штучно проголошують окремою мовою L2 і кодифікують iiï стандарт (L2s), хоча достатніх передумов для творення нової мовної сингулярності нема.

Натомість різновид |L3| утворив два підрізновиди |L3.1| та |L3.2|, що пройшли різного ступеню внутрішню еволюцію і утворили дві окремі мовні сингулярності L3.1 та L3.2, але через політичні обставини вони надалі дефініюються як одна мова.

Отже, графік мовних сингулярностей не обов'язково збігатиметься 3 графіком мов. Штучноутворені мови з часом можуть стати окремими мовними сингулярностями, якщо під час стандартизації та корпусного планування максимально віддалити літературний стандарт від мови походження і ефективно його імплементувати.

Так само дві окремі мовні сингулярності можна довгий час класифікувати як одну мову. Ці обидва сценарії доволі поширені.

Тепер спробуємо показати, як працює модель мовних сингулярностей на прикладі історії української мови.

Славистика XXIII/1 (2019) 
154

Лесь Белей

За Ю. Шевельовим, після розпаду праслов'янської мови у східних слов'ян сформувалося п'ять діалектів:

1) новгородсько-тверський (НТ);

2) києво-поліський (КП);

3) муромо-рязанський (МР);

4) полоцько-смоленський (ПС);

5) галицько-подільський (ГП) (Шевельов 1994: 25).

Ці діалекти лягли в основу формування російської, української та білоруської мов. Процес формування тривав з VI по XIV ст. (ibid.) На схемі творення мовних сингулярностей цей процес можна зобразити так, як на Схемі 14

Схема 14

$\mathrm{L}$ - це праслов'янська мова, що дійшла до етапу дивергентного творення мовних сингулярнсотей і серед інших мала 6 регіональних різновидів, що лягли в

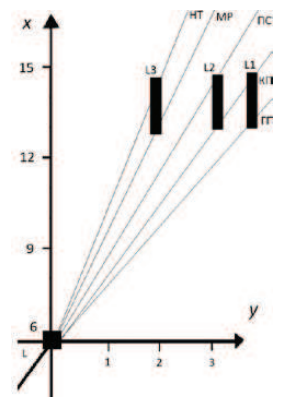

основу трьох нових мовних сингулярностей. L1 - української (києво-поліський і галицько-подільський), L2 - білоруської (києво-поліський і полоцько-смоленський), L3 - російської (новгородсько-тиверський та муромо-рязанський). Так виглядає протоукраїнський період за класифікацією Шевельова (VII - XI ст.) (Шевельов 2002: 46).

Давньоукраїнський (XI - XIV ст.) та середньоукраїнський (XV - XVIII) періоди можна схематично зобразити як на Схемі 15.
Еволюиія мов: иодель сингуяярностей

Схема 15

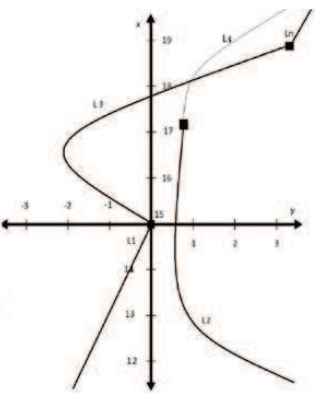

3 ХІ ст. відбувається контакт давньоруської мови (тобто києво-поліського та галицько-волинського діалектів) (L1) зі старослов'янською мовою, точніше церковнослов'янською мовою, що формує українську редакцію (L2). У XV ст. мовна сингулярність середньоукраїнського періоду (L3) (утворена під впливом церковнослов'янської) починає інтенсивно полонізуватися, зважаючи на тодішні геополітичні умови, пік припадає на XVI - XVII ст. Далі мова починає поступово відчищати цей вплив (оскільки геополітичні умови змінилися).

У 1618 р. відбувається остаточна кодифікація церковно-слов'янської (граматика М. Смотрицького), що стає літературною нормою (Ls) на два століття.

Тим часом на базі L3 постає нова мовна сингулярність (Ln) наприкінці XVIII ст. (Водночас починається перегляд літературного стандарту Ls i наближення його до живорозмовної основи.

У різних державах регіональні різновиди української у цей період піддаються впливам місцевих суперстратних та адстратних мов з різною інтенсивністю: на Наддніпрянщині-російської, на Галичині-польської та німецької, на Закарпатті - угорської. Найбільше це відображається на лексико-фразеологічному рівні, менше на морфологічно-синтаксичному. Натомість діалектні відмінності на фонетико-просодичному рівні варіюють під впливом внутрішньомовної еволюції.

На Наддніпрянщині відбувається інтенсивний вплив російської аж до початку XX ст., зумовлений політичним тиском (відсутність україномовної освіти, Валуєвський циркуляр, Емський указ). Потім на хвилі українізації відбувається внутрішньомовна еволюція (творення і впорядкування лексики, фразеології, морфологічно-синтаксичних норм), але після згортання українізації знову відновлюється русифікація (La1, Lb1). Фонетико-просодичний рівень (Lc1) майже не змінюється див. Схему 16. 
156

Лесь Белей

Схема 16

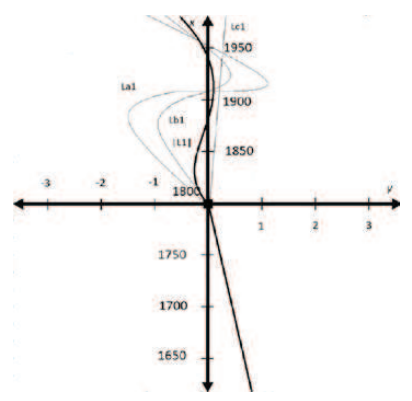

На Галичині активні польські впливи тривають до кінця першої світової, далі місцевий різновид української робить певний опір і після приєднання Галичини до УРСР почався процес зближення галицького регіонального різновиду 3 наддніпрянським див. Схему 17.

Схема 17

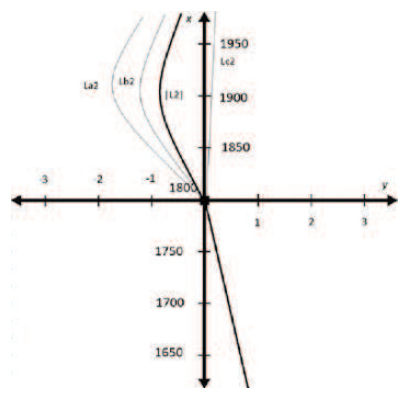

Подібна ситуація була й на Закарпатті, тільки місцевий різновид української був довший час ізольований i зазнав сильніших впливів, ніж галицький. Угорщина вела сильну мадяризаційну політику, кульмінацією якої став закон Аппоні 1907 року. 31918 по 1939 тут також додався чеський суперстратний вплив див. Схему 18.
Еволюуія иов: иодеть сингулярностей

Схема 18

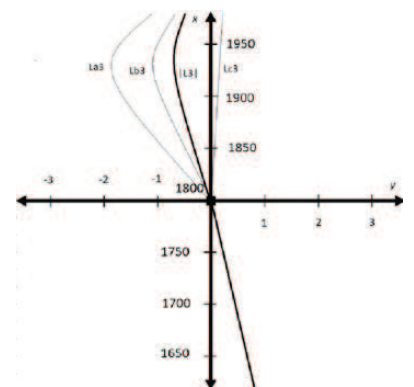

На базі закарпатських регіональних різновидів (суттєво відмінних між собою) розроблено політичний проект утворення штучної мови, так званої русинської, хоча ці різновиди не дійшли до точки творення нової мовної сингулярності.

Графіки діахронічного розвитку української мови можна деталізувати більш точно прокреслити лінії мовного розвитку. Для цієї статті ми обрали схематичність, щоб продемонструвати на практиці застосування моделі мовних сингулярностей.

Ця модель може стати зручним інструментом у діахронічному аналізі. Поперше, вона деполітизована і уникає дискусій про мови та діалекти. По-друге, ця модель зручно ілюструє внутрішньомовні зміни та взаємовпливи мов у часовій перспективі. По-третє, враховуються параметри мовної політики та мовного планування, якщо вони мають реальний вплив на мовну еволюцію.

\section{Використана література}

Борисенко, Олександр. Диференціальна геометрія і топологія. Харків: Основа, 1995 Єжов, Станіслав, Маргарита, Разумова. Теорія функцій комплексної змінної. - Київ: Київський університет, 2012.

Шевельов, Юрій. Історична фонологія української мови. Харків: Акта, 2002.

Шевельов, Юрій. Чому общеруський язик, а не вічно-руська мова? Київ: КМ Академія, 1994

Gosselin, Clement, Jorge, Angeles «Singularity analysis of closed-loop kinematic chains» IEEE Transactions on Robotics and Automation. Vol. 6, Issue: 3, 1990: 281-290.

Holzkämpfer, Hendrik. Management von Singularitäten und Chaos. Wiesbaden:Springer, 1996.

Hawking S. The beginning of Time $<w w w . h a w k i n g . o r g . u k / t h e-b e g i n n i n g-o f-t i m e . h t m l>$ 10.11.2018.

Kaschula R., Mostert M. From Linguistic Determinism to Technological Determinism 
$<$ http://www.irma-international.org/viewtitle/112898/> 8.11.2018.

Khan S. Towards a linguistic singularity. $<$ http://harvardpolitics.com/world/towards-linguistic-singularity/> 12.11.2018.

Lamb, Horace. "Types and spells of weather around the year in the British Isles: Annual trends, seasonal structure of the year, singularities" Quarterly Journal of the Royal Meteorological Society. №76/330, 1950: 393-438.

Maxwell, James, Clerk. „Does the Progress of Physical Science tend to give any Advantage to the Opinion of Necessity (or Determinism) over that of the Contingency of Events and the Freedom of the Will?" [in:] L. Champbell, W. Garnett (eds.) The Life of James Clerk Maxwell. London:McMillan, 1882, 434-444p.

Schleicher, August. Compendium der indogermanischen Sprachen. Weimar:Böhlau, 1861. Schmidt, Johannes. Die Verwandtschaftsverhältnisse der indogermanischen Sprachen. Weimar:Böhlau, 1872.

Shanahan, Murray. The Technological Singularity. Boston:MIT Press, 2015.

Лес Белеј

\section{ЕВОЛУЦИЈА ЈЕЗИКА: МОДЕЛ СИНГУЛАРИТЕТА}

\section{Резиме}

У раду је описан модел језичких сингуларитета као инструмент вишедимензионалног одсликавања језичке еволуције, који узима у обзир како унутрашње језичке промене тако и утицаје других језика. Аутор предлаже синтетички модел помоћу којег могу бити приказане језичке промене на различитим нивома, укључно са регионалним варијететима и кодификованим стандардима, с обзиром на брзину и интензитет промена. Практична примена модела језичких сингуларитета је приказана на примеру историје украјинског језика.

Кључне речи: језички сингуларитет, дијахронија, синхронија, језик, дијалекат, језичка политика. 